\title{
SVEIKATOS PRIEŽIŪROS VADYBOS RAIDA LIETUVOJE: POKYČIIAI, TENDENCIJOS, KRITINIS POŽIŪRIS, TARPTAUTINIS KONTEKSTAS
}

\author{
Vinsas Janušonis \\ Klaipèdos universitetinè ligoniné, Klaipédos universitetas
}

Raktažodžiai: sveikatos priežiūros vadyba, išteklių valdymas, centralizacija.

\begin{abstract}
Santrauka
Darbo tikslas: įvertinti sveikatos priežiūros vadybos raidą ir esminius pokyčius Lietuvos sveikatos apsaugos sistemoje ir jos organizacijose.

Analizuota įvairių šalių mokslinès publikacijos sveikatos priežiūros vadybos klausimais, statistiniai duomenys, teisès aktai. Visa tai sisteminta ir vertinta.

Darbe atskleisti profesionalios sveikatos priežiūros vadybos ir bendrosios vadybos esminiai skirtumai bei parodytas sveikatos priežiūros vadybos sudètingumas. Pateikta sveikatos priežiūros sistemos ir jos organizacijų vadybos bei vadybos mokslo raida, atskleisti esminiai jos vystymosi trikdžiai.

Daroma išvada, kad nepaisant įvairių trikdžių ir neigiamų momentų, sveikatos priežiūros vadyba šalyje vystèsi ir tobulèjo, dèl to gerèjo ir pati sveikatos priežiūra.
\end{abstract}

\section{Ivadas}

Šiuolaikinis vadybos mokslas, remdamasis kritiniu požiūriu ị tradicinę vadybą, jos sampratos, metodinių žinių, praktikos ir ideologijos hegemoniją, kelia daug iššūkių ir reikalauja netradicinių pokyčių.

Pagrindinis akcentas - profesionali vadyba, atspindinti tam tikros sistemos ir jos organizacijų interesus, naudą, veiklos stimulus, perspektyvas.

Profesionalios veiklos pagrindas - specifinès žinios, apibendrinančios veiklos turinį ir veikimo būdus. Specifinès žinios - tai ne tik aplamai vadybos, bet ir tam tikros srities (sveikatos priežiūros) žinios, supratimas, kaip specifinè sistema ir jos organizacijos veikia, kaip užtikrinti optimalų jų funkcionavimą [1-3]. Sveikatos priežiūros vadyba skiriasi nuo vadybos apskritai tiek, kiek skiriasi sveikatos priežiūros organizacijos nuo kitų organizacijų - t.y. labai daug. Ji yra bendrujų vadybos žinių ir specialiujų medicinos (sveikatos priežiūros) žinių hibridas.

Ji lyg paslèpta, nematoma. Kalbėdami ar galvodami apie sveikatos priežiūrą žmonès mato medikus, gydytojus ar slaugytojus, atliktas sudètingas operacijas, naujus vaistus ar gydymo metodus, bet nemato sveikatos priežiūros vadybos, kuri visa tai suteikia. Jie mato sveikatos priežiūros progresą, bet nesuvokia kaip jis atsiranda ir plinta. Sveikatos priežiūros vadybininkų veiklą žmonès neretai supranta kaip rūpinimąsi daugiau pinigais, nei pacientais. Visuomenès informacijos priemonès, kartais net pačios sistemos vadovybè sveikatos priežiūros organizacijų vadovus nušviečia neigiamai. Nors būtent jie daro esminę ịtaką sveikatos priežiūros prieinamumui, tinkamumui, kokybei. Deja, to kai kada nesupranta net ir patys sistemos vadovai - sveikatos priežiūros vadyba ne mažiau sudètinga, sunki ir atsakinga profesija nei chirurgo ar patologo ir vadovauti sveikatos priežiūros organizacijai negali ,bet kas“.

Išskirtinis sveikatos priežiūros vadybos bruožas - jos sąsajos su žmonių sveikata ir gyvybe, abipusis priklausomumas.

Sveikatos priežiūros vadybos paradigma formuojama i̇rodymais pagrisstos medicinos ir sveikatos pagrindu [4]. Sveikatos priežiūros sistemos ir organizacijų vadyba tiesiogiai susijusi su pacientų sveikatos priežiūra ir medikų klinikiniais sprendimais $[5,6]$.

Sveikatos priežiūros sistemos ir jos organizacijų (ypač jų) vadybai būdingi tam tikri esminiai momentai, darantys ją sudètingą, sunkią, kartais sunkiai prognozuojama veikla:

- nuolatinis lèšų stygius, išteklių ribotumas;

- išsilavinęs, aukšto intelekto personalas;

- nerealūs politikų ir pacientų lūkesčiai;

- suteiktų galių ir atsakomybės neatitikimas;

- rezultatu priklausomybè nuo individualios organizacijos narių veiklos;

- sistemos atsiliepiamumo (pasiūlos ir paklausos neatitikimo) problemos. 
Visa tai - veiklos specifiškumas, sudètingumas, svarba visuomenei - sveikatos priežiūros vadybą paverčia išskirtine veikla bendroje vadybos plotmejje, reikalaujančia ypatingų vadybos mechanizmų, specifinių gebejjimų, žinių.

Realioje sveikatos priežiūros vadybos veikloje susiduriama su daugybe dichotomijų, dilemų, paradoksų, interesų konfliktu - su tuo ženkliai mažiau susiduria tradicinė bendroji vadyba $[7,2,8]$.

Darbo tikslas - ịvertinti sveikatos priežiūros vadybos raidą ir esminius pokyčius Lietuvos sveikatos apsaugos sistemoje ir jos organizacijose.

\section{Tyrimo objektas ir metodologija}

Tyrimo objektas - sveikatos priežiūros sistemos ir organizacijų vadyba. Tyrimo metodai - įvairių šalių sveikatos priežiūros vadybos mokslinių tyrimų publikacijų analizė, lyginamoji analize, ivvertinimas; statistinių duomenų sisteminimas, analizè ir vertinimas; ịvairių Lietuvos įstatymų ir Sveikatos apsaugos ministerijos, kitų institucijų teisès aktų analizè ir vertinimas.

\section{Rezultatai ir jų aptarimas}

Sveikatos priežiūros vadybos raidoje galima išskirti du aspektus - sistemos ir jos organizacijų vadybos bei mokslo vystymąsi ir profesijos susiformavimą.

Sveikatos priežiūros vadybos mokymo programa pirmą kartą buvo įdiegta $1900 \mathrm{~m}$. JAV, Niujorke, Kolumbijos mokytojų kolegijoje [9], ligoninių administratoriai - daugumoje gydytojai. 1929 m. išleista pirmoji knyga sveikatos priežiūros vadybos tema (Michael Davis „Hospital Administration, a Career: the Need for Trained Executives for a Billion Dollar Business, and How They May Be Trained").

Buvo pripažinta, kad sveikatos priežiūros organizacijos (ligoninès) yra ne tik medicinos institucijos, bet kartu socialinès bei verslo organizacijos, kurioms būtina ypač profesionali vadyba, integruojanti ịvairias profesijas ir jų veiklas, ryšius su mokslo ir mokymo institucijomis, aprūpinimą ištekliais.

Sveikatos priežiūros vadybos, kaip specialybès, statusą itvirtino $1934 \mathrm{~m}$. Čikagos universiteto ligoninių vadybos (vèliau pakeista ị sveikatos priežiūros vadybos) programa.

Praeitame šimtmetyje naujų teorijų šviesoje iš esmès pasikeite tiek sveikatos priežiūros organizacijos, tiek jų vadyba.

Buvo suformuluotos kelios sveikatos priežiūros vadybos nuostatos [10]:

- atsakomybè už finansinę organizacijų veiklą ir finansinị stabilumą;

- žmogiškujų išteklių, ypač medikų vadyba - jų veiklos organizavimas, kvalifikacijos kèlimas, duomenų rinkimas ir analizè;

- socialinè vadovų atsakomybè už bazinę sveikatos priežiūrą ligoniams - ypač pažeidžiamai žmonių grupei;

- atsakomybė už organizacijų tvarumą - organizacinę kultūrą, moralinị klimatą joje, profesinių grupių sąveiką, organizacijos atsparumą išorinei aplinkai.

Panašūs procesai, gal kiek pavèluoti vyko ir Lietuvoje. Jau trečiajame dešimtmetyje, tuoj pat po šalies nepriklausomybès atkūrimo pradèti bendrosios vadybos tyrimai, skelbtos publikacijos. Pažymètini J.Šimkaus, P.Raulinaičio, S.Nacevičiaus, G.Galvanausko, V.Graičiūno, P.Lesauskio darbai. $1939 \mathrm{~m}$. buvo ịkurta mokslinès vadybos draugija. Tačiau sveikatos priežiūroje vadyba nebuvo akcentuojama, daugiau dèmesio buvo skiriama medicinai, ligų gydymui ir jų prevencijai. Nors jau $1918 \mathrm{~m}$. buvo ịkurta sveikatos komisija (vèliau pervadinta sveikatos departamentu) ir sveikatos apsaugos sistema buvo valdoma. Reikia pažymèti, kad jau $1921 \mathrm{~m}$. pirmajame gydytojų suvažiavime V.Tercijonas padarè vadybini pranešimą „Sveikatos apsaugos organizavimo reikalu“. Šiame pranešime buvo akcentuojami du svarbiausi klausimai: sveikatos priežiūros prieinamumas ir racionalumas.

Tuo metu sveikatos priežiūros organizacijų (ligoninių) vadovų darbas nebuvo populiarus. Jau tada buvo pastebeta, kad ne kiekvienas senas geras gydytojas gali būti geru plačios srities administratoriumi [11].

Sovietiniu laikotarpiu sveikatos apsaugos valdymui buvo skiriama pakankamai daug demesio, tačiau jis vyko pagal rusiškajị Semaškos modelį. Izoliacija nuo pasaulio, privataus sektoriaus nebuvimas, centralizuotas planavimas ir valdymas neleido vadybai tinkamai vystytis. Tačiau net ir tokiomis sąlygomis Lietuvoje buvo puikių sveikatos priežiūros vadybininkų - V. Kleiza, B. Kisielius, P. Jašinskas, A. Vinkus ir kt. Buvo paskelbtos pirmosios monografijos sveikatos priežiūros vadybos tema (V. Janušonis „Medicinos pagalbos kokybè ir valdymas“, 1990).

Viena didesnių sovietinio laikotarpio sveikatos priežiūros vadybos problemų buvo biurokratija. Tikètasi, kad atkūrus šalies nepriklausomybę ji mažès. Tačiau trumpam sumažèjusi, biurokratija nepaliaujamai didẻja, reikalauja naujų materialinių ir žmonių išteklių. Ją skatina ir biurokratinis ES aparatas.

Antai šalies sveikatos priežiūros ịstaigose dokumentų apyvarta per 25 metus padidèjo kelis kartus. Pavyzdžiui, Klaipèdos universitetinèje ligoninèje išleidžiamų ịsakymų skaičius nuo 493 (1991 m.) išaugo iki 2671 (2016 m.), gaunamų (ieinančių) raštų kiekis nuo 907 (1991 m.) išaugo iki 4216 (2016 m.), siunčiamų raštų skaičius nuo 3272 (1991 m.) išaugo iki 7799 (2016 m.). 
Vèl atkūrus nepriklausomybę sveikatos priežiūros vadybos mokslas pradejo stipriai vystytis, buvo skelbiami straipsniai, monografijos, ginamos disertacijos. Sveikatos priežiūros vadybininkai buvo pradèti ruošti universitetuose. $2010 \mathrm{~m}$. Klaipedos universitete atidaryta sveikatos priežiūros vadybos magistrantūros programa (vadovas - V.Janušonis). Susiformavo sveikatos priežiūros vadybos mokslininkų, daugiausia medikų grupè - E.Smilga, V.Grabauskas, V.Janušonis, D.Jankauskienè, J. Kairys, J.Petrauskienè, R.Kalèdienè ir kiti.

İrodymais (mokslu) grịsta vadyba būtina sveikatos priežiūros sistemos ir jos organizacijų veiklai, funkcijų vykdymui.

Sveikatos priežiūros sistema atlieka keturias pagrindines funkcijas [12]: teikia sveikatos priežiūrą (1), generuoja žmogiškuosius ir materialinius išteklius, kad ši priežiūra būtų galima (2), didina ir kaupia išteklius, reikalingus sveikatos priežiūrai (3), tvarko, reguliuoja visą sistemą (4).

Sveikatos priežiūros sistemos vadyba, kurią faktiškai vykdo Sveikatos apsaugos ministerija (ministras), apibrèžiama tinkamu šių funkcijų vykdymu. Ši vadyba glaudžiai siejasi, tiksliau - stipriai veikiama šalies sveikatos politikos. Ši, priklausydama nuo bendrosios politikos, ne visada yra loginè ir racionali - neretai ji remiasi esamaja politine jèga bei interesais ir dèl to, keičiantis politinèms jègoms, kinta kartu.

Reikia pažymėti, nors sveikatos politika Lietuvoje buvo pakankamai nuosekli, orientuota i Pasaulio sveikatos organizacijos (PSO) ir Europos Sajungos (ES) sveikatos politiką, sistemos vadyba stipriai varijavo, ji buvo nuolat (ne visada pamatuotai) reformuojama, mèginamos spręsti problemos, bet ne jų priežastys.

Lietuvoje buvo įvykdytos dvi konceptualios sveikatos priežiūros sistemos reformos - praeito amžiaus paskutinio dešimtmečio pradžioje, kai buvo atsisakyta Semaškos modelio, ir 1997 m., kai buvo pereita prie draudiminès medicinos ir viešujų sveikatos priežiūros ịstaigų modelio.

Pagrindiniai sveikatos priežiūros teikimo aspektai, akcentuojami tiek pacientų (žmonių), tiek politikų - sveikatos priežiūros prieinamumas ir tinkamumas.

Iš esmès tiek sveikatos priežiūros prieinamumas, tiek tinkamumas (kokybė) Lietuvoje gerẻjo.

Sistemos sąranga, šeimos gydytojo ir gydytojų - konsultantų institucijos, išvystytas ligoninių tinklas garantavo pakankamą prieinamumą, kuris, tikimasi, dar pagerès igyvendinus naujas, ịsigaliosiančias 2018 m. sveikatos priežiūros isstaigu ịstatymo nuostatas.

Žinoma, galima diskutuoti dèl pirminès ir antrinès sveikatos priežiūros atskyrimo ir apjungimo, patekimo pas gydytojus specialistus, siuntimų tvarkos, šeimos gydytojų funkcijų išplètimo, antrinio ir tretinio sveikatos priežiūros lygių sklaidos ir integracijos, gydytojų ir slaugytojų trūkumo, tačiau tai bendros tendencijos nekeičia.

Žmogiškujų išteklių generavimas - tai gydytojų, slaugytojų, kitų sveikatos priežiūros specialistų ruošimas. Šia prasme Lietuva užima vieną pirmaujančių pozicijų ES. Jau per pirmuosius kelis metus po nepriklausomybès atkūrimo buvo reformuotas gydytojų, kiek vẻliau ir slaugytojų ruošimas. İvesta ịvairių lygių rezidentūra pagal specialybių sudètingumą, išplèstas rezidentūros bazių tinklas, slaugos specialistai pradèti ruošti universitetuose, reformuotos i aukštąsias mokyklas kolegijos.

Pradèti ruošti sveikatos priežiūros vadybininkai - šio profilio magistrantūros atsiranda LSMU, KU, VU.

Pamažu, tačiau pastaruoju metu auga BVP dalis, skiriama sveikatos priežiūrai.

Išteklių kaupimas yra labai svarbus, tačiau dar svarbesnis jų paskirstymas, kuris šalyje yra gana kontraversiškas.

Pagrindiniai išteklių kaupimo fondai yra penki - privalomo sveikatos draudimo fondas (PSDF) (1), ES plètros struktūrinių fondų lèšos (2), Valstybès biudžeto lèšos (3), istaigos uždirbtos (be PSDF) lèšos (4), kitos lèšos (5).

PSDF lëšomis disponuoja bei jas skirsto Valstybinè ligonių kasa (VLK) ir teritorinès ligonių kasos (TLK), vadovaudamosios Sveikatos apsaugos ministerijos (SAM) ịsakymais. Tačiau nuo 2003 m. VLK tapus sveikatos apsaugos ministerijai pavaldžiu struktūriniu vienetu, susidarè labai ydinga padètis - visų išteklių paskirstymą sprendžia viena institucija, $\mathrm{o}$ iš esmès vienas žmogus (ministras).

Pastaraisiais metais atsisakyta suinteresuotų sveikatos priežiūros organizacijų atstovų darbo grupių, kurios teiktų savo išvadas dèl galimo struktūrinių ir investicinių fondų lèšų paskirstymo atskiroms įstaigoms. Šių lëšų skirstymas iš esmès tapo vienasmenis.

ES lěšas, kaip ir PSDF lěšas skirsto SAM. Kitų ministerijų dispozicijoje esančias ES lěšas, susijusias su sveikatos priežiūra, skirsto taip pat SAM. Valstybès biudžeto lěšas per ivairias programas taip pat skirsto SAM.

Pats didžiausias šio skirstymo ydingumas: jos nèra uždirbamos, nèra ịtrauktos ị sveikatos priežiūros paslaugų kainą, o „duodamos“ - skiriamos papildomai. Toks skirstymas dirbtinai ịstaigas reitinguoja - net labai intensyviai ir našiai dirbančios ịstaigos, negaudamos papildomo finansavimo, gali būti reitingų gale.

Gaudamos papildomų lèšų remontui, technologijoms ìstaigos atsilaisvinusias lèšas gali skirti papildomų specialistų prièmimui, atlyginimų didinimui.

Absoliuti didžiuma ,programinių“ lešş skiriama universitetų ligoninèms. Niekas neabejoja, kad joms jų reikia, 
tačiau tai nereiškia, kad kitoms sveikatos priežiūros įstaigoms jų nereikia.

Dauguma mokslininkų sutinka, kad sveikatos priežiūros sistema turetų būti labiau reguliuojama nei kitos sistemos, tačiau reguliavimas turi būti protingas, netrukdantis organizaciju ir medikų veiklai, ir neturintis neigiamos įtakos pacientų sveikatos priežiūrai ir sveikatai.

Šalies sveikatos priežiūros sistemos ir jos organizacijų reguliavimas yra didelis ir jis vis auga.

Politineje sferoje egzistuoja mitas, kad kuo daugiau sveikatos priežiūra reguliuojama, tuo ji geresnè, kokybiškesnè, prieinamesnè.

Reguliuojamos tokios veiklos sritys:

- profesinis reguliavimas - medikų ruošimas, licencijavimas, atlyginimų reguliavimas, kvalifikacijos kèlimas, užsieniečių medikų įdarbinimas ir kt.;

- finansinis reguliavimas - PSDF skirstymas, sutartys su ligonių kasomis, ES struktūrinių ir kitų finansinių fondų skirstymas, paslaugų kainų nustatymas, mokamų paslaugų teikimo reguliavimas ir kt.;

- organizacijų veiklos reguliavimas - licencijavimas, reikalavimų struktūrai ir veiklai nustatymas, leidimai teikti vienas ar kitas paslaugas, sudaryti sutartis, viešieji pirkimai ir kt.;

- technologinis reguliavimas - leidimai vienai ar kitai įrangai ịsigyti, lèšų ịrangos ịsigijimui skirstymas, ịvairių technologinių tyrimų apmokejjimas, reikalavimų e-sveikatai nustatymas ir kt.;

- bendrasis reguliavimas - reikalavimas deklaruoti interesus ir turtą medikams, ịvairios (SAM, ligonių kasų, akreditavimo tarnybos) kontrolès formos, minimalių algu didinimas ir kt.;

- farmacinis reguliavimas - vaistinių tinklai, vaistų kainos, kompensuojamieji vaistai, vaistų saugumas ir veiksmingumas ir kt.

Neperteklinis sistemos tvarkymas, jos reguliavimas yra reikalingas. Čia pažymètini keli susiję su paslaugų ir ịstaigų tinklo reformomis aspektai - sveikatos priežiūros ịstaigu ir ligonių kasų santykis (1), sveikatos priežiūros įstaigų pavaldumas (2), įstaigų autonomija (3).

Pasaulio šiuolaikinèje sveikatos priežiūros vadyboje taikomas sveikatos priežiūros paslaugų moketojų ir paslaugų teikejjų funkcijų atskyrimo principas. Lietuvoje šio principo laikomasi vis mažiau - keičiant ịstatymus ir poịstatyminius teisès aktus (SAM įsakymus) šios funkcijos vis labiau suliejamos, net iki to - kad ligonių kasos kontroliuoja ūkinę - finansinę sveikatos priežiūros įstaigų veiklą, neturèdamos jokios atsakomybès.

Centralizuotas (komandinis-kontrolinis) sveikatos prie- žiūros valdymas yra nedaugelyje šalių (JK, Danija). Ryškiausias pavyzdys - JK, kur valstybė dominuoja ir sveikatos priežiūros reguliavimas yra labai ženklus. Jis nèra labai efektyvus - didžiulès išlaidos ir kuklūs rezultatai. JK ir Danija nepatenka ị geriausių sveikatos priežiūros sistemų šalių 16-tuką [13].

Dèl šios priežasties centralizacijos ir pilnos valstybès institucijų kontrolès, organizuojant sveikatos priežiūros sistemų ir jos organizacijų darbą, metodas taikomas retai - tik identifikavus tokias sveikatos priežiūros sistemos problemas bei jų priežastis, kurių negalima išspręsti jokiais kitais metodais. Sveikatos priežiūros centralizacija - daugiau politikų nei pacientų interesas, susietas daugiau su finansavimu, nei su sveikatos priežiūros rezultatais, kaip ir daugelis kitų reformų $[14,15]$.

Pagrindiniai principai šiuolaikinèje sveikatos priežiūros organizacijų vadyboje - jų autonomija ir decentralizacija. Tai pripažistama ypač efektyviu sveikatos priežiūros veiklos mechanizmu $[16,2,17]$.

Sveikatos priežiūros prieinamumas - vienas labiausiai turinčiu įtakos veiksnių pacientų sveikatai ir jų pasitenkinimui sveikatos priežiūra. Prieinamumą užtikrina tinkamas (pakankamas) sveikatos priežiūros finansavimas ir pačių isstaigų suinteresuotumas, t.y. jų decentralizuota autonominé veikla $[18,6]$. I tai orientuotos šalių sistemos - vienos geriausių (Liuksemburgas, Belgija, Vokietija, Prancūzija, Austrija).

Minimalią autonomiją šalies sveikatos priežiūros ịstaigos (SPĮ) išlaikè. Tačiau laipsniškai sveikatos priežiūra vis labiau centralizuojama - SAM valdo (yra dalininkè) beveik visas didžiąsias daugiaprofilines sveikatos priežiūros ịstaigas, joms skiria didžiumą išteklių. Taip sudaromos nevienodos ìstaigų veiklos sąlygos ir atitinkamai nevienodos pacientų sveikatos priežiūros sąlygos (prieinamumas, kokybiška sveikatos priežiūra).

Decentralizacija pasireiškia (vykdoma) ịvairiais metodais:

- įstaigų plètros ir veiklos monopolizacijos ribojimas;

- konkurencijos skatinimas regionuose (kelių panašios veiklos profilių įstaigų buvimas);

- dekoncentracija - ịstaigų pavaldumo perdavimas ar dalinis perdavimas savivaldybèms;

- devoliucija - organizacijų valdymo ir kontrolès funkcijų iš SAM perdavimas savivaldybèms;

- delegavimas - atsakomybès ir reguliavimo funkcijų perdavimas pačioms organizacijoms;

- privatizavimas - viešojo ir privataus sektoriaus santykio, teikiant paslaugas nustatymas, reikalavimų sveikatos priežiūros ịstaigų kūrimuisi supaprastinimas.

Decentralizacija išsprendžia visą eilę problemų ir yra 
atsakas į neefektyvų ekonominių ir žmonių išteklių valdymą, lètą technologinį progresą, nepakankamą pacientų poreikių tenkinimą.

Reikètų išskirti sveikatos priežiūros kokybę ir su ja susijusius aspektus - nepageidautinus ịvykius, eiles, pakartotines hospitalizacijas, pacientų pasitenkinimą, kaip tinkamos sveikatos priežiūros vadybos rezultatą [17, 23].

Pacientai supranta sveikatos priežiūros paslaugos vertę ir kokybę, tačiau neretai nesupranta, kaip ji sukuriama ir kiek priklauso nuo finansinių išteklių bei jų paskirstymo mechanizmų.

Sveikatos priežiūros kokybę stipriai veikia ištekliai, jų paskirstymas, tai minèta anksčiau.

Pažymètina, kad panašiose sveikatos priežiūros ịstaigose (ligoninèse) panašiais ištekliais pasiekiama skirtinga sveikatos priežiūros kokybė ir jos veiklos rezultatai. O tai jau vadybos objektas - medikų kvalifikacija ir jų pakankamumas, technologijų naujumas, darbo našumas. Šiuolaikinès technologijos (taip pat ir informacinès) iš esmès apsprendžia sveikatos priežiūros kokybę ir gali būti sveikatos priežiūros sistemos ir jos organizacijų efektyvios veiklos matas [19].

Medicininès technologijos vystėsi, jų daugejo ir šiuo metu jų naujumas ir pakankamumas artēja prie minimalių ES normatyvų (vidurkių).

Technologiniu aspektu Lietuva užima tinkamą vietą ES. Ypač atnaujintos technologijos per pastaruosius penkerius metus - atsirado pozitronų emisijos tomografija (PET) LSMU Kauno ir VU Santaros klinikose minimaliai pakanka magnetinio rezonanso (MRT) ir kompiuterinès tomografijos aparatų (KT). KT aparatų skaičius nuo $42000 \mathrm{~m}$. padidejo iki 662016 m., MRT aparatų skaičius nuo 12000 m. iki 35 $2016 \mathrm{~m}$. Veikia keturi branduolinès medicinos - linijinių greitintuvų ir brachiterapijų centrai, šiuolaikinès gama kameros. Šiuolaikiniai ultragarsiniai aparatai, endoskopai, elektrokardiografai tapo rutinine įranga kiekvienoje SPİ. Ruošiamasi ịsigyti stereotaksinę įrangą LSMU Kauno klinikose.

Tačiau lètai judama link robotinių technologijų.

Šioje srityje daugiau problemų dèl technologijų išdèstymo (reguliavimo), ir jos aštrèja. Motyvuojant brangiu technologijų išdėstymo racionalumu ir išteklių taupymu šią reguliavimo funkciją priskyre sau ministerija ir pastaraisiais metais vyksta technologijų centralizacija universitetu klinikose ir jų ribojimas kitose ligoninèse.

Tarkime, yra motyvuotas, gerais norais grịstas SAM įsakymas dèl brangios medicinos įrangos įsigijimo. Vis dèlto jis labai tiktų esant biudžetinei įstaigų finansavimo sistemai... Vèlgi SAM, nors SPI galioja konkurencijos ir bankroto ịstatymai, sprendžia, kuri ịstaiga gali (net savo uždirbtomis lëšomis) ịsigyti vieną ar kitą brangią technologiją, o kuri ne- gali. O juk pora metų metų neleidžiant didelei ịstaigai ịsigyti naujų technologijų, ji tiesiog taps ,neiggalia“, negalinčia teikti kokybiškos sveikatos priežiūros pacientams.

Sveikatos priežiūros funkcionavimas (veikla) ypač priklauso nuo sistemos ir jos organizacijų vadybos. Nors neretai teigiama, kad sistemos finansavimas priklauso nuo išorinès (politinès, ekonominès) aplinkos, tačiau sistemai vadovaujantis ministras yra valdančiosios daugumos atstovas ir Vyriausybès narys, todèl nuo jo labai priklauso sistemos finansavimas.

Kitos sistemos funkcionavimui būtinos sudedamosios - išteklių (žmogiškujų, informacinių, materialinių, finansinių) pritraukimas ir tinkamas paskirstymas, informacinių ir medicininių technologijų vystymas ir tinkamas išdėstymas, sveikatos priežiūros procesų struktūrizavimas ir kontrolè, sveikatos priežiūros decentralizavimas ir organizacijų autonomija [20-22, 2, 17].

Lietuvoje, nors BVP nuo $2000 \mathrm{~m}$. ženkliai augo, tačiau jo dalis sveikatos priežiūrai augo lètai iki 2009 m., o vèliau mažèjo ir tik pastaraisiais metais turi tendenciją šiek tiek augti.

BVP Lietuvoje nuo 10 milijardų JAV dolerių kasmet 1995-2000 m. išaugo iki 42,74 milijardų JAV dolerių 2016 m. (148 $80 \mathrm{JAV}$ dolerių vienam gyventojui). Tuo tarpu visų išlaidų sveikatos priežiūrai BVP dalis nuo 5 proc. $2000 \mathrm{~m}$. augo iki 7,45 proc. 2009 m., o vèliau mažèjo. 2016 m. BPV dalis sveikatos priežiūrai sudare 6,4 proc., iš kurių valstybè skyre tik 3,9 proc., likę 2,5 proc. buvo apmoketa pačių žmonių [24].

Finansinių išteklių nepakankamumas - tik viena problemos pusè. Antai Singapūro sveikatos priežiūros sistema eilę metų yra viena geriausių pasaulyje $(2017 \mathrm{~m}$. - antroje vietoje, vidutinè gyvenimo trukme $83 \mathrm{~m}$.), o BVP dalis sveikatos priežiūrai tik 4,6 proc.

Antroji šios problemos pusè - jų paskirstymas. Iš dalies - tai paslaugų apmokejjimo mechanizmas - nors šalyje jis tobulinamas, tačiau išlieka ydingas (,plaukiojantis balas“, ribojama metinè paslaugų apmokèjimo suma organizacijoms, paslaugų kainos neatitinka kaštų ir kt.).

Esminė problema - apmokejjimas ne už paslaugą, kaip galutinị sveikatos priežiūros organizacijų veiklos produktą, bet ịvairus programinis finansavimas, pinigu ,davimas“, bet ne jų uždirbimas. Be to, tiek finansinių išteklių paskirstymas (paslaugų apmokèjimas ir kt.), tiek sveikatos priežiūros paslaugų užsakymo bei teikimo reguliavimas yra centralizuotas SAM.

Finansinių išteklių paskirstymas visą laiką buvo netolygus, jų paskirstymo mechanizmas ydingas ir jis netobulejo. Jis iki šiol nèra skirtas esminèms sveikatos priežiūros pro- 
blemoms spręsti.

Žmogiškieji ištekliai (gydytojai, slaugytojai, vadybininkai ir kt.) buvo ruošiami ir plètojami gerai, tačiau dèl šalies vidinès aplinkos, neprognozuojamos ir nestabilios sistemos veiklos, nepakankamų atlyginimų didejjo specialistų medikų emigracija bei jų darbas ne pagal ịgytą specialybę ir augo jų trūkumas. Nors tiek gydytojų, tiek slaugytojų ruošimas universitetuose ir kolegijose buvo pakankamas ir augo - dirbančių gydytojų skaičius augo nuo $36,42000 \mathrm{~m}$. iki 44,99 2016 m., slaugytojų nekito - 80,53 $2000 \mathrm{~m}$. ir 80,83 2016 m. 10.000 gyventojų. Per pastaruosius $15 \mathrm{~m}$. beveik tris kartus išaugo visuomenès sveikatos (sveikatos priežiūros vadybos) studijas baigusiujų skaičius - nuo $182001 \mathrm{~m}$. iki kelių šimtų $2016 \mathrm{~m}$. Sveikatos priežiūros vadybininkų ruošimas - teigiamas procesas, tačiau jie sistemoje yra nepaklausūs ir sveikatos priežiūros įstaigų vadyboje ịtakos nedaro. Profesionali (sveikatos priežiūros) vadyba medicinos profilio organizacijų vadyboje nèra paklausi, kai kurių politikų nuomone, gal net nereikalinga.

Informacinè bazè, informaciniai ištekliai nežiūrint ị tam tikrus trikdžius (objektyvius bei subjektyvius) sveikatos priežiūroje buvo vystomi ir yra minimaliai pakankami.

Materialinių ir kitų išteklių pritraukimas galètų būti žymiai efektyvesnis, plačiau bendradarbiaujant viešajam ir privačiam sveikatos priežiūros sektoriui ir tam panaudojant privataus sektoriaus kapitalą.

Asmens sveikatos priežiūros įstaigų skaičius mažejo ir $2016 \mathrm{~m}$. jų buvo 274 (juridiniai vienetai), iš jų 84 ligoninès.

Mažèjo lovų skaičius ligoninèse - nuo nepriklausomybẻs atkūrimo aktyvaus gydymo lovų skaičius sumažejo per pusę ir $2016 \mathrm{~m}$. buvo 49,32 lovos 10000 gyventojų. Privati sveikatos priežiūra plètėsi pamažu. Per pastaraji dešimtmetį ligoninių skaičius išliko toks pat (12 juridinių vienetų), augo ambulatorinių - konsultacinių SPI skaičius.

Sveikatos priežiūros procesų struktūrizavimo ir kontrolès procesas vystèsi ir tobulejjo, tačiau kartu buvo vis labiau centralizuojamas.

Teigiami momentai sveikatos priežiūros sistemos vadyboje - dèmesys eilèms (sveikatos priežiūros prieinamumui) ir atitinkamas įstatymų koregavimas, dèmesys sveikatos priežiūros kokybei, nepageidautinų ịvykių registravimui, prasidèjęs įstaigu akreditavimo procesas, reikalavimai išorinei kokybès kontrolei.

Pakankama (kol kas), nors ir mažinama sveikatos priežiūros įstaigų autonomija.

Nepaisant įvairių nuokrypių ir trikdžių, šalies sveikatos priežiūros sistema, jos pačios ir organizacijų (ypač!) vadybos dèka vystèsi ir tobulëjo link saugesnès, kokybiškesnès, efektyvesnès, labiau naudingos pacientams, prieinamesnès sveikatos priežiūros.

Vertinant pagal Europos sveikatos vartotojų rodiklių grupes $[25,26]$ Lietuvoje:

1. Sveikatos priežiūros sritys yra pakankamo ir tinkamo lygio.

1.1. pacientų teisès ir jų informavimas;

1.2. aprūpinimas vaistais;

1.3. laukimo laikas stacionariniam gydymui (planinėms operacijoms);

1.4. rezultatai (kūdikių mirtingumas ir kt.);

1.5. ilgalaikè sveikatos priežiūra (reabilitacija, palaikomasis gydymas ir slauga);

1.6. dienos chirurgija;

1.7. sveikatos priežiūros kokybè (sistema, išorinès kokybės vertinimo sistemos, nepageidautinų įvykių registracija ir kt.).

2. Sveikatos priežiūros sritys yra nepakankamo ar netinkamo lygio:

2.1. e-sveikata;

2.2. laukimo laikas (eilès) pas šeimos gydytoją ir gydytojus konsultantus;

2.3. rezultatai (savižudybès, vidutinè gyvenimo trukmè ir kt.);

2.4. visuomenès sveikata (investicijos);

2.5. reformos.

Nors labiausiai sveikatos priežiūros veiklą ir jos rezultatus atspindi su sistema susietas gyventojų mirtingumas (ịvairūs jo aspektai), nepageidautini ịvykiai (ịvairūs rizikos aspektai, pakartotinès hospitalizacijos) [27, 22, 23], tačiau tai darbinis, supaprastintas vertinimo metodas.

Sveikatos priežiūros sistemos ir jos organizacijų veikla, procesai vykstantys sistemoje yra labai sudettingi ir sunkiai suprantami neprofesionaliems (sveikatos priežiūros požiūriu) vadybininkams, politikams.

Supaprastinti sistemos ir jos veiklos rezultatu vertinimo rodikliai dažnai būna politizuoti ir ginčytini, abejotini.

Sveikatos priežiūros sistemos ir jos organizacijų vadyba priklauso daugiau nuo išorinės aplinkos ir kitų sistemų bei organizacijų, nei nuo vidinių sistemos intervencijų (reformų) $[28,2]$. Tiek sveikatos priežiūros sistema, tiek jos organizacijos yra stipriai ,irèminta“ (reguliavimas, pacientų ir politikų spaudimas, nepakankamas finansavimas, nuolatinès reformos ir kt.), todèl vadybinè veikla čia taip pat labai , ,rėminta“ ir ìvairiai interpretuojama.

\section{Išvados}

1. Vieni didžiausių tinkamos sveikatos priežiūros vadybos trikdžių šalyje yra centralizacija, neprofesionalumas, didejjanti biurokratija, išteklių nepakankamumas ir ydinga jų 
paskirstymo metodologija, nuolatinès reformos, sąlygojančios sistemos ir jos organizacijų nestabilumą bei neprognozuojamumą, paslaugų mokètojų (ligonių kasų) ir jų tiekejų (sveikatos priežiūros organizacijų) funkcijų neatskyrimas.

2. Sveikatos priežiūros vadyba bei jos išdava - pati sveikatos priežiūra Lietuvoje, nepaisant įvairių trikdžių ir banguotumo vystėsi, tobulëjo ir lygiuojasi ị pažangias Europos ir pasaulio šalis.

3. Tinkamos sveikatos priežiūros ir jos vadybos trikdžių ir barjerų pašalinimas bei vengimas naujų nereikalauja papildomų išteklių ir gana nesunkiai ịgyvendinamas, sutvarkant veikiančius įstatymus ir poịstatyminius teisès aktus.

\section{Literatūra}

1. Ferdinand J, Muzio D, O'Mahomey J. Special book review: studying management critically. Organizations Studies, 2004; 25: $1455-1465$

https://doi.org/10.1177/0170840604046352

2. Janušonis V. Sveikatos apsaugos sistemos organizacijų valdymas. Klaipėda: S. Jokužio leidykla-spaustuvė, 2012.

3. Zakarevičius P. Vadybos mokslas Lietuvoje. Kaunas: KTU "Technologija", 2015.

4. Moskowitz D, Bodenheimer T. Moving from evidence based medicine to evidence based health. Journal of General Internal Medicine 2011; 26: 658-660.

https://doi.org/10.1007/s11606-010-1606-4

5. Patrician PA, Loan L, McCarthly M. et al. Towards evidence based management: creating an informative database of nursing sensitive indicators. Journal of Nursing Scholarship 2010; 42: 358-366.

https://doi.org/10.1111/j.1547-5069.2010.01364.x

6. Janušonis V. İrodymais pagrịstos sveikatos priežiūros organizacijų valdymas. Tiltai, 2011; 4: 1-12.

7. Learmonth M, Harding N, eds. Unmasking health management: a critical text. New York: Nova Science Publishing, 2004.

8. Yukl G.A. Leadership in Organizations. Boston: Pearson, 2013.

9. Stevens R. In sickness and in wealth: American hospital in the twentieth century. Baltimore: The Johns Hopkins University Press, 1999.

10. Haddock CC, McLean RA, Chapman RC. Careers in healthcare management: how to find your path and follow it. Chicago: Health Administration Press, 2002.

11. Janušonis V. Profilaktinè medicina Lietuvoje: 1918-1940 m. Klaipeda: Rytas, 1992.

12. World Health Organization. The World Health Report 2000. Health systems: improving performance. Geneva: WHO, 2000.

13. Martin W. The 16 countries with the world's best healthcare systems, 2017; http://nordic.businessinsider.com

14. Magnussen J, Vrangbaek K, Saltman RB. Nordic health care systems: recent reforms and current policy challenges. Berkshire: Open University Press, 2009.
15. Blank RH, Burau V. Comparative health policy. Basingstoke: Palgrave Macmillan, 2010.

16. Ridic G., Gleason S., Ridic O. Comparisons of health care systems in the United States, Germany and Canada, Material Sociomedica, 2012: 24: 112-120. https://doi.org/10.5455/msm.2012.24.112-120

17. Janušonis V. Organizacinè elgsena ir kokybė sveikatos priežiūroje: integracinè-sisteminė apžvalga. Klaipėda: S.Jokužio leidykla-spaustuvè, 2017.

18. Reibling M. Healthcare systems in Europe: towards an incorporation of patient access. Journal of European Social Policy 2012; 20: 5-18.

https://doi.org/10.1177/0958928709352406

19. Gauld R. The new health policy. Maidenhead: Open University Press, 2009.

20. Murray JL, Frenk J. A framework for assessing the performance of health systems. Bulletin of the World Health Organisation, 2000; 78: 717-731.

21. Murray CJL, Evans DB. eds. Health systems performance assessment: debates, methods and empiricism. Geneva: WHO, 2003.

22. Smith PC, Mossialos E, Papanicolas J, Leatherman S. Performance measurement for health system improvement: experiences, challenges and prospects. Cambridge: Cambridge University Press, 2009.

23. Janušonis V. Adverse events - one of the most important health care quality indicators: a case study. European Scientific Journal 2017; 13: 288-300.

https://doi.org/10.19044/esj.2017.v13n12p288

24. Sveikatos apsaugos ministras: turime sutvarkyti sveikatos sistemą, 2016; https://sam.lrv.lt.

25. HCP. The empowerment of the European patient. Brussels: Health Consumer Powerhouse, 2009.

26. HCP. Euro Health Consumer Index report. Brussels: Health Consumer Powerhouse, 2012.

27. Porter ME. What is value in health care? New England Journal of Medicine 2010; 363: 2477-2481. https://doi.org/10.1056/NEJMp1011024

28. Cylus J, Papanicolas J, Smith PC. Health system efficiency: how to make measurement matter for policy and management. Copenhagen: World Health organization, 2016.

\section{HEALTH CARE MANAGEMENT DEVELOPMENT IN LITHUANIA: CHANGES, TRENDS, CRITICAL APPROACH, INTERNATIONAL CONTEXT V. Janušonis}

Key words: healthcare management, resources managemed, centralization.

Summary

The aim of the study - the assessment of healthcare management development and the main changes in the healthcare system and its organizations in Lithuania. 
Methods. The analysis, structuring and comparison of scientific publications, statistical date and legislation.

Results. The study revealed the main differences between the professional and the general management and showed the complexity of healthcare management. Given the evolution of healthcare management and health care management science, the barriers of their development.

Conclusion. Some of the biggest barriers of health care management in Lithuania are centralization, lack of professionalism, the growing burocracy, inadequacy of resources and defective its allocation methodology, permanent reforms, instability and unpredictability of the healthcare system and organizations, non separa- tion of functions of payers for healthcare services (sickness funds) and their suppliers (healthcare organizations).

Country's health care management and health care services as its outcome has evolved and improved, and is in touch with the developed Europe and World countries. The elimination and avoidance of healthcare management barriers do not require additional resources and easily accessible with the adjustment of legislation.

Correspondence to: janusonis@kul.lt

Gauta 2017-11-06 